\title{
ONTWIKKELINGSASPEKTE VAN KERNMISSIELE
}

LT T. VAN RENSBURG*

The development of nuclear missiles with special reference to the Soviet Union and the USA is dealt with. Ballistic Missiles, Cruiser Missiles and the strategic implications of the development of the latter are analysed. The author then proceeds to discuss the development of the Neutron bomb and its application as well as the implications of its application.

\section{Inleiding}

Op 6 en 9 Augustus 1945 is twee atoombomme vanuit Amerikaanse B-29 bomwerpers onderskeidelik op twee Japanse stede neergelaat die eerstes en enigstes wat tot dusver as oorlogswapentuig aangewend is. Dit ly vandag geen twyfel dat bogenoemde gebeurtenisse 'n omwenteling in oorlogvoering meegebring en 'n nuwe era in internasionale verhoudinge ingelui het nie. Volskaalse oorlogsvoering en die aanwending van kernwapens is vandag nouliks denkbaar, maar hierdie wapentuig vervul tans 'n belangrike afskrikkingsfunksie in die verhoudings tussen die groot moondhede. Oorlogsvoorkoming is in dié verband van primêre belang en is ' $n$ doelwit wat alleen gehandhaaf kan word indien daar voortdurend gestreef word na strategiese kernparaatheid. In hoofsaak beteken dit dat die supermoondhede elk oor ' $n$ eie kernvergeldingsvermoë moet beskik om in die geval van kernaggressie weerwraak te waarborg, soveel so, dat nie een van hulle kan bekostig om 'n kernkonflik deur 'n openingsaanval te inisieer nie. In kernstrategie is daar dus belangrike militêrtegnologiese ontwikkelinge ten opsigte van kernwapens en die aanwending daarvan, ten einde oor die vermoë van oorlewingspotensiaal ('second-strike' of 'strike-back capability') te beskik. Enkele ontwikkelingsaspekte van kernmissiele word in die lig van die voorafgaande vervolgens aan die orde gestel.

\section{Interkontinentale ballistiese missiele}

Drie suksesvolle vuurpyllanserings deur die USSR in 1957 was die eerste aanduiding van die toetrede van interkontinentale ballistiese missiele (ICBM) tot die kerneeu. Op 3 Augustus 1957 is 'n Sowjet SS-6 ICBM vanaf sy lanseerbasis vir ' $n$ paar duisend kilometer tot in sy teikengebied, die Siberiese yswoestyn, gevuur. Hierdie gebeurtenis was aanvanklik met beperkte openbare belangstelling begroet, maar wye reaksie het gevolg nadat die USSR op 4 Oktober 1957 en 3
November 1957 onderskeidelik Sputnik 1 en Sputnik 2, die eerste aardsatelliete, in 'n wentelbaan om die aarde geplaas het. ${ }^{1}$

Amerikaanse navorsing op hierdie terrein het gedurende Junie 1957 uitgeloop op 'n mislukte toetsvlug van die 4-A missiel, die eerste Atlas-missiel wat vir hierdie doeleindes ontwikkel is. Een minuut na lansering het hierdie Atlasmissiel heeltemal uitgebrand nadat dit masjienprobleme ondervind het. Op 25 September 1957 het ' $n$ tweede Atlas-toets misluk en eers in November 1958 kon die VSA daarin slaag om 'n suksesvolle Atlas-lansering te voltooi - een jaar na die Sputniksuksesse. ${ }^{2}$

Die VSA was merkbaar onkant gevang deur die voorafgaande gebeurtenisse, veral gesien in die lig van sy onbevraagtekende tegnologiese superioriteit sedert die begin van die kerneeu. Die werklike implikasies van die Sowjet-voorsprong was egter strategies van aard in soverre dit ' $n$ kernvermoë vir 'n openingsaanval aan die USSR kon verseker. ${ }^{3}$ Hierdie vermoë het egter nie gerealiseer nie, alhoewel die Amerikaners erg begaan was oor die sogenaamde 'missile gap', synde die numeriese agterstand in ballistiese missiele wat die VSA in die sestigerjare tegemoet sou gaan. Bogenoemde verwikkelinge het ook 'n rol gespeel in die 1960-presidentsverkiesing waartydens president Kennedy aan bewind gekom het en gedurende sy termyn verseker het dat enige 'agterstand' wat moontlik mag bestaan, uitgewis word. ${ }^{4}$

Die ontwikkeling van die interkontinentale ballistiese missiel was die vertrekpunt van verskeie belangrike missielontwikkelingsaspekte van die kerneeu. Dit het militêr-tegnologies sowel as polities-strategies belangrike afmetings aangeneem en vind hedendaags vergestalting in die Amerikaanse Minuteman-reeks en die Russiese SS-reeks wat beide ' $n$ trefafstand van 10000 of meer kilometers kan behaal. ${ }^{5}$ Ontwikkelingsaspekte wat besonder dramatiese invloed op 
kernwapentuig het, is die aanwending van meervoudige onafhanklike kernplofkoppe op een enkele missiel, die ontwikkeling van die kruisermissiel en die neutronplofkop waarmee missiele tQegerus kan word.

\section{Meervoudige onafhanklike kernplof- koppe vir enkel missiele}

\subsection{Die ontwikkeling van die MIRV-konsep}

Die Sowjet-lansering van Sputnik 1 en die ontwikkeling wat daarop gevolg het, het aanleiding gegee tot ' $n$ aansienlike mate van vooruitgang in die Amerikaanse militêr-industriële gemeenskap. In noue kompetisie met die USSR oor interkontinentale ballistiese missiele en burgerlike sowel as militêre ruimteprogramme (byvoorbeeld ' $n$ bemande ruimtetuig), het tegnologiese aspekte rondom strategiese kernmissiele 'n bloeitydperk in die VSA beleef. In hierdie oplewing het die tegnologiese vermoë om meervoudige onafhanklike kernplofkoppe vir enkel missiele te vervaardig, beslag gekry. ${ }^{6}$

Gedurende 1961 en 1962 het die USSR verskeie aansprake gemaak ten opsigte van 'n projektielafweervermoë, soveel so dat premier Khrushchev in Julie 1962 verklaar dat Sowjet-ABM ' . . . could hit a fly in outer space'. In dieselfde jaar het president Kennedy soos volg op hierdie bravade gereageer: 'He might hit a fly but whether he could hit a thousand flies with decoys - you see, every missile that comes might have four or five missiles in it, or would appear to be missiles, and the radar screen has to pick those out and hit them going thousands of miles an hour and select which one is the real missile and which are the decoys'. ${ }^{7}$

Teen die agtergrond van die voorafgaande het die VSA in 1964 die eerste missiel met meervoudige kernplofkoppe (Polaris A-3) operasioneel ontplooi in die Polaris-tipe duikboot. Hierdie missiel het drie onafhanklike kernplofkoppe gedra wat meganies ontkoppel kon word sodat dit dieselfde teiken in 'n driehoekverband kon tref. Hierdie wapentuig was egter slegs 'n interimontwikkeling aangesien navorsing toegespits was op enkel meervoudige onafhanklik-doelwitgerigte projektiele ('multiple independently-targeted reentry vehicle' - MIRV) waarmee verskillende teikens getref kon word. Op 16 Augustus 1968 is die eerste toetsvlugte met MIRV-toegeruste missiele vir beide die Minuteman III en Poseidon onderneem, en gedurende 1970 en 1971 is
MIRV-missiele ontplooi in bogenoemde verband. Die Minuteman III was toegerus met drie van hierdie tipe projektiele, terwyl die Poseidon C-3 missiel vir kernduikbote tussen tien en veertien soortgelyke projektiele kon $\mathrm{dra}^{8}$

Verskeie redes word vir die motivering van die MIRV-tegnologie aangevoer soos byvoorbeeld die volgende: reaksie op Sowjet ABMverwikkelinge (projektielafweervermoë); as die mees ekonomiese teenvoeter vir opponerende teikenveelvuldigheid; die momentum van missieltegnologie; en die mees effektiewe wyse, met inbegrip van die koste-faktor, om 'n afskrikkingsvermoë te handhaaf sonder om 'n getalsvermeerdering van uiters duur missiele tot gevolg te hê. In die breë kan egter aangeneem word dat 'n verskeidenheid faktore die ontwikkeling van die MIRV-tegnọlogie gerugsteun riet, soos Greeńwood tereg opmerk: "In short, technology, strategy, politics and organisational factors were all woven together in an intricate, unique and changing fabric. Untill 1968 the main strands all tended in the same direction, carrying MIRV programs forward'. 9

\subsection{Die MIRV-tegnologie}

Die MIRV-tegnologie stel een enkele missiel in staat om verskeie kernprojektiele (kernplofkoppe) op verskillende teikens te rig, of om dieselfde teiken langs verskillende bane te bereik. Hierdie tegnologiese vermoë word vervolgens saaklik uiteengesit:

Die finale fase van die missiel wat deur die voorafgaande vuurpylfases die ruimte in gelanseer is, staan bekend as die 'Post Boost Control System' (PBCS), of 'bus' in algemene terme, en bestaan uit die verskillende kernprojektiele ('re-entry vehicles') en die beheer- en geleidingstelsel ('guidance and control system'). Hierdie finale draerbus is in staat om sy snelheid, wentelbaan en eie oriëntasie na gelang van die vereiste te verander by wyse van miniatuur vuurpylmotore ('small vernier rockets'). Wanneer hierdie draerbus in sy beplande wentelbaan gemaneuvreer is, soos in ooreenstemming met die teiken wat dit ten doel het, kan die eerste projektiel vrygelaat word. Die projektiele beskik nie oor 'n eie aandrywingsvermoë nie, maar 'val' of 'stuur' in ooreenstemming met die rigting en die baan waarin dit vrygelaat word. Wanneer die vrylating van die eerste projektiel voltooi is, verander die draerbus sy baan, snelheid en/of oriëntasie ten einde in posisie gestel te word vir die vrylating van die tweede projektiel en die 
peiling van die volgende teiken. Hierdie proses duur voort tot al die projektiele wat deur die draerbus gedra word, vrygelaat is. ${ }^{10}$

Die draerbus kan ook met fopmeganismes toegerus word in die plek van sommige projektiele om die opponent se projektielafweerstelsel te fnuik of uit te put, en om sodoende die teikengerigte projektiele se vermoë om hul teikens te bereik, te verhoog. Die kompakte draerbus moet in terme van gewig en grootte beperk word om by die oorhoofse missielontwerp in te pas. In hierdie verband is aansienlike vooruitgang gemaak ten opsigte van die kernplofkoppe se elektroniese samestelling en die verhouding tussen hulle gewig en plofkrag ('yield-to-weight ratio'). Die beheer- en geleidingstelsel moet voorts toegerus wees met 'n rekenaarvermoë om byvoorbeeld teikendata te stoor, om elke projektiel se 'lansering' te verwerk en om stabiele (gebalanseerde) voortgang te verseker met die vrylating van elke projektiel. Die MIRV-tegnologie hou ten slotte ook verband met die verhouding tussen die volgende aspekte: die aantal plofkoppe; die plofkrag per plofkop; die verspreiding van teikens; totale reikvermoë; en deurdringingsvermoë. ${ }^{11}$

\subsection{MIRV en 'n kernvergeldingsvermoë}

Die ontwikkeling van MIRV-toegeruste kernmissiele het 'n besliste uitwerking gehad op kernvergeldingsvermoëns. Die MIRV-tegnologie het die deurdringingsvermoë van kernmissiele drasties verhoog. As gevolg van die vermeerdering in kernplofkoppe waarmee meer teikens vernietig kan word, sowel as die akkuraatheidsverbetering van die teikengerigte projektiele, het 'n MIRV-tipe kernwapen uitgekristalliseer as ' $n$ baie effektiewe wapen teen die kernopponent se strategiese grondmagte. Juis hierdie aspekte het die kwesbaarheid van statiese silogebergte kernmissiele uitgelig en die belangrikheid beklemtoon van die ontplooiing van kernmissiele in mobiele/bergingstelsels, sowel as in kernduikbote. ${ }^{12}$

Die MIRV-ontwikkeling het ook strategie in die breë beïnvloed. Tammen toon aan hoedat MIRV in sy vroeë fase geen doeltreffende 'harde-teiken vernietigingsvermoë' opgelewer het nie, maar wel later as gevolg van tegnologiese verbetering tot 'n besliste vermoë in hierdie verband uitgekristalliseer het. ${ }^{13}$ MIRV het die geloofwaardigheid van die Amerikaanse kernafskrikkingsvermoë sowel as die algemene vertroue van die Amerikaanse volk versterk. Daar bestaan ten slotte meningsverskil of die MIRV-ontwikkeling stabiliserend ingewerk het op tussenstaatlike terreurewewig, terwyl dit ook probleme kan oplewer ten opsigte van die wapenwedloop en wapenkontrole. ${ }^{14}$

\section{Die kruisermissiel}

\subsection{Die ontwikkeling van die kruisermissiel}

Die ontwikkeling van eksakte geleide-tipe wapentuig ('precision guided munitions') vind waarskynlik die beste motivering in die woorde van Ashmore: 'It has always been a temptation to dream of beating one's enemies, easily and spectacularly, following some scientific breakthrough, some technical leap forward of decisive impact'. ${ }^{15}$

Die eerste aanduidings van eksakte geleide-tipe wapentuig in die vorm van onbemande selfaangedrewe geleide toerusting, kan reeds nagespeur word in Amerikaanse navorsing gedurende die dertigerjare. Hierdie navorsing het onder andere die ontwikkeling van vliegtuig-landingsisteme by wyse van instrumente en 'n televisiegeleidingseenheid ingesluit. Die kruisermissiel ontwikkelingskonsep het egter eers stimulus verkry gedurende die Tweede Wêreldoorlog met die aanwending van die Duitse $V-1$, of sogenaamde 'buzz bomb', wat 'n straalaangedrewe missiel was met ' $n$ plofkop wat etlike honderde myle gelanseer kon word, alhoewel sonder enige akkuraatheid. Gedurende 1946 het die Amerikaanse Vloot onderneem om op hierdie Duitsemodel voort te bou ten einde 'n duikboot gelanseerde missielvermoë te ontwikkel in die gedaante van Regulus I. Tot en met 1958, toe die kollig van missielnavorsing verskuif het na die ontwikkeling van die ICBM, het verskeie Amerikaanse kruisermissiele reeds die lig gesien (onder andere Navaho, Snark, Mace, Hounddog and Regulus II). Hierdie missiele was egter gekortwiek deur aspekte soos swaar plofkoppe, oneffektiewe aandrywing- en geleidingsisteme, onakkuraatheid en kwesbaarheid. ${ }^{16}$

Die suksesvolle taktiese aanwending van geleide missiele gedurende die Viëtnam-oorlog aan die einde van die sestigerjare en die ontwikkeling van soortgelyke wapentuig sedert daardie tydperk, het hernude belangstelling in hierdie veld ontketen. Gedurende 1972 het die VSA 'n ontwikkelingsprogram vir 'sea launched cruise missiles' (SLCM) van stapel gestuur wat beslag gekry het in die Tomahawk-kruisermissiel. In 


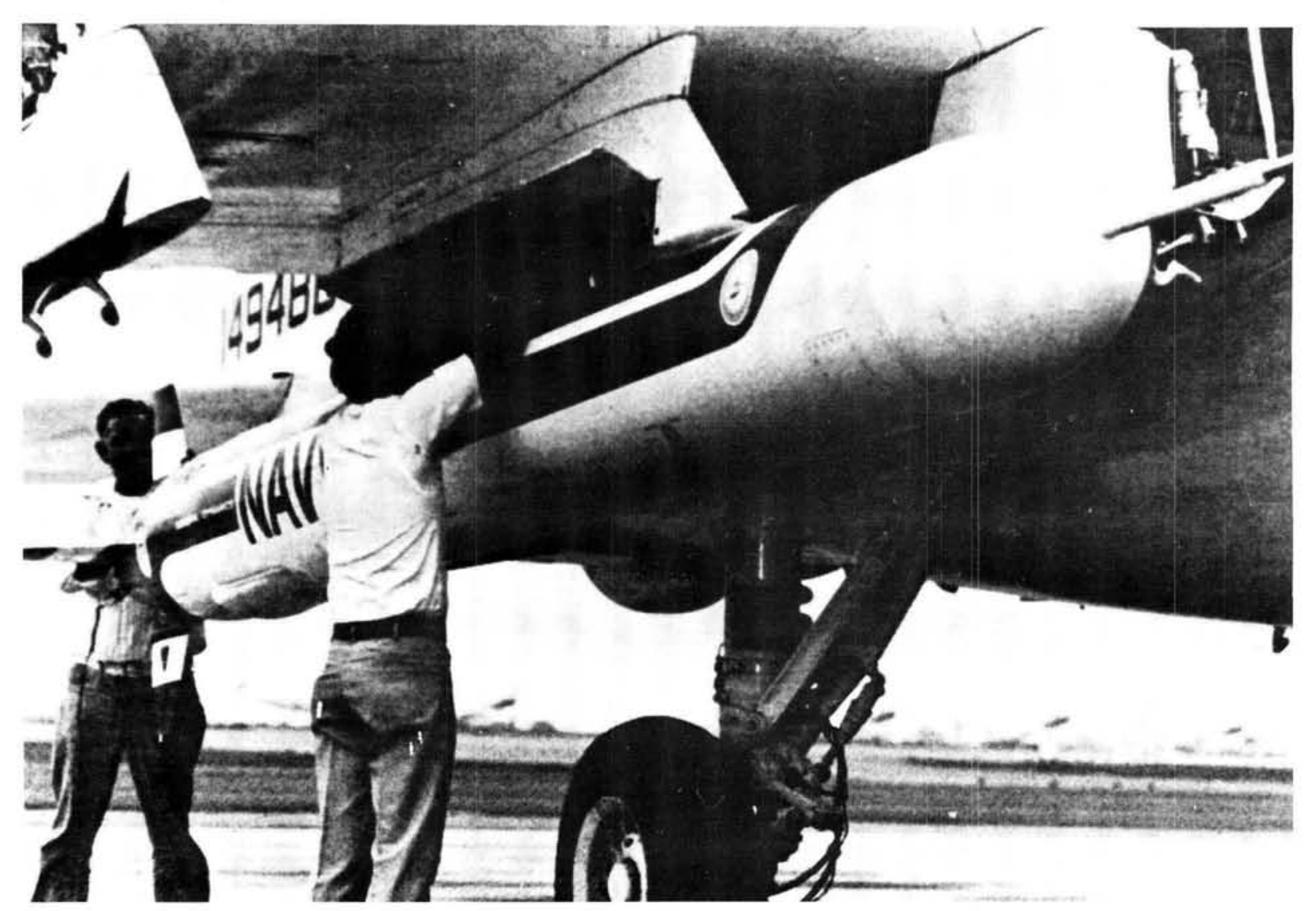

Die Tomahawk-kruisermissiel kan vanaf 'n verskeidenheid van platforms lanseer word. Hier word dit op 'n VSA Vloot A-6 Intrudar-vliegtuig gelaai.

1974 het die ontwikkeling van 'n strategiese 'air-launched cruise missile' (ALCM) 'n aanvang geneem ten einde die potensiële aanwending van die kruisermissiel-tegnologie verder te eksploiteer. Op 13 Februarie 1976 is die eerste toetsvlug van die duikboot-gelanseerde kruisermissiel onderneem en met die aanvang van die tagtigerjare was die kruisermissiel reeds vanaf 'n verskeidenheid lanseerplatforms getoets, soos die duikboot, bomwerper, voertuig en skepe. ${ }^{17}$

\subsection{Die kruisermissiel-tegnologie}

Die kruisermissiel word soos volg deur Tsipis gedefinieer: 'A cruise missile can be defined as a dispensable, pilotless, self-guided, continuously powered, air-breathing warhead - delivery vehicle that flies just like an airplane, supported by aerodynamic surfaces'. ${ }^{18}$ Die vernaamste doelwit met hierdie tipe wapentuig is om te verseker dat elke 'skoot wat gevuur word' die teiken tref. ${ }^{19}$

Die hedendaagse kruisermissiel is 'n omvattende tegnologiese verbetering op al sy voorgangers. Die vernaamste verbeterings lê opgesluit in sy mikro-elektroniese apparaat waardeur geleiding vir akkuraatheid bewerkstellig word en die effektiewe aandrywing deur turbine-tipe enjins. Vanweë die kruisermissiel se vermoë om baie laag oor die aardoppervlak te stuur (rofweg $20 \mathrm{~m}$ bokant die see, $50 \mathrm{~m}$ bokant die landskap en 100 $\mathrm{m}$ bokant berge) is dit baie moeilik opspoorbaar deur radarstelsels. Die enigște nadeel van die kruisermissiel is geleë in die feit dat indien dit eers deur opponerende teenmaatreëls opgespoor is, dit 'n onvermoë het om daarop te reageer vir eie oorlewing. Die probleme verbonde aan die opsoor van kruisermissiele is egter ' $n$ uiters ingewikkelde aangeleentheid waarop daar nog geen doeltreffende antwoord bestaan nie. ${ }^{20}$

Die kruisermissiel het sy lang reikafstand (ongeveer 2000 seemyle) te danke aan die liggewig turbine-tipe enjins waarmee dit toegerus word, naamlik die waaier- en straalturbine ('turbofan' en 'turbojet'). Die waaierturbine enjin, alhoewel duurder as die straalturbine, is spesiaal ontwerp vir subsoniese spoed, langafstande en 'n dravermoë vir kernplofkoppe, terwyl dit ook meer brandstofbesparend is en 'n laer temperatuur met betrekking tot uitlaatgasse oplewer. Die hoë 
temperature van uitlaatgasse veroorsaak 'n infrarooi 'opspoorbaarheid' wat sover as moontlik beperk moet word. Die groote van die waaierturbine is ongeveer 75 sentimeter in lengte. ${ }^{21}$

In vergelyking met die interkontinentale ballistiese missiel wat slegs die eerste vyf minute van die ongeveer twintig minute wat dit hom sou neem om $5000 \mathrm{~km}$ af te lê, gelei word, sal dit die kruisermissiel ongeveer ses ure neem om dieselfde afstand met voortdurende geleiding te voltooi. Uit die voorafgaande is dit duidelik dat ten spyte van sy 'reistyd' die sukses van die kruisermissiel ongetwyfeld op sy geleidingsvermoë berus. In eenvoudige terme berus hierdie geleiding op beskikbare gerekenariseerde data van die terrein en die teiken, die verwerking en vergelyking van die terrein waaroor beweeg word en die aanpassing van afwykings van die beplande roete waarlangs die vlug plaasvind. Die kruisermissiel kan vir akkurate geleiding ondersteun word deur terrein/kontoer- en areakorrelasie tegnieke ('terrain-contour-matching technique' of TERCOM, en die 'area-correlation technique'), sowel as die aardplasingsatellietstelsel ('global-positioning-satellite tech- nique'). Akkuraatheid kan op bogenoemde wyse bewerkstellig word tot ' $n$ CEP (straalfout) van minder as twaalf meter. ${ }^{22}$

Die langafstand strategiese kruisermissiel dra 'n W-80 kernplofkop met ' $n$ deursnee van ongeveer 26 sentimeter en ' $n$ plofkrag van 200 tot 250 kiloton TNT. Benewens bogenoemde kompaktheid kan die totale lengte van die kruisermissiel wissel van ongeveer 3,85 meter tot 6,25 meter, met ' $n$ deursnee van 50 sentimeter of minder. Die kruisermissiel se kostevergelyking met dié van die Minuteman (ICBM) is ongeveer $1: 3$ (rofweg 10 miljoen tot 32 miljoen 1976 Amerikaanse dollars vir ' $n$ tien jaar 'life-cycle-cost'), en behoort nog beter te vergelyk met die nuwe MX ICBM-stelsel. Koste effektiwiteit van die kruisermissiel toon ' $n$ verdere verbetering indien faktore soos kwesbaarheid, akkuraatheid, deurdringingsvermoë en lansering ingereken word. Vanweë sy kompakte samestelling beskik die kruisermissiel oor ' $n$ verskeidenheid bestaande lanseerplatforms waarby dit aangepas kan word. Hierdie lanseerplatforms sluit die volgende in: strategiese bomwerpers ( $\mathrm{B}-52$ en $\mathrm{B}-1)$ en verskeie aangepaste vliegtuie soos byvoorbeeld die Boeing 747 ,

AGM - 86B (ALCM) Aërodinamiese modelle word op die vierk piloon van 'n Boeing B-52G Bomwerper gelaai.

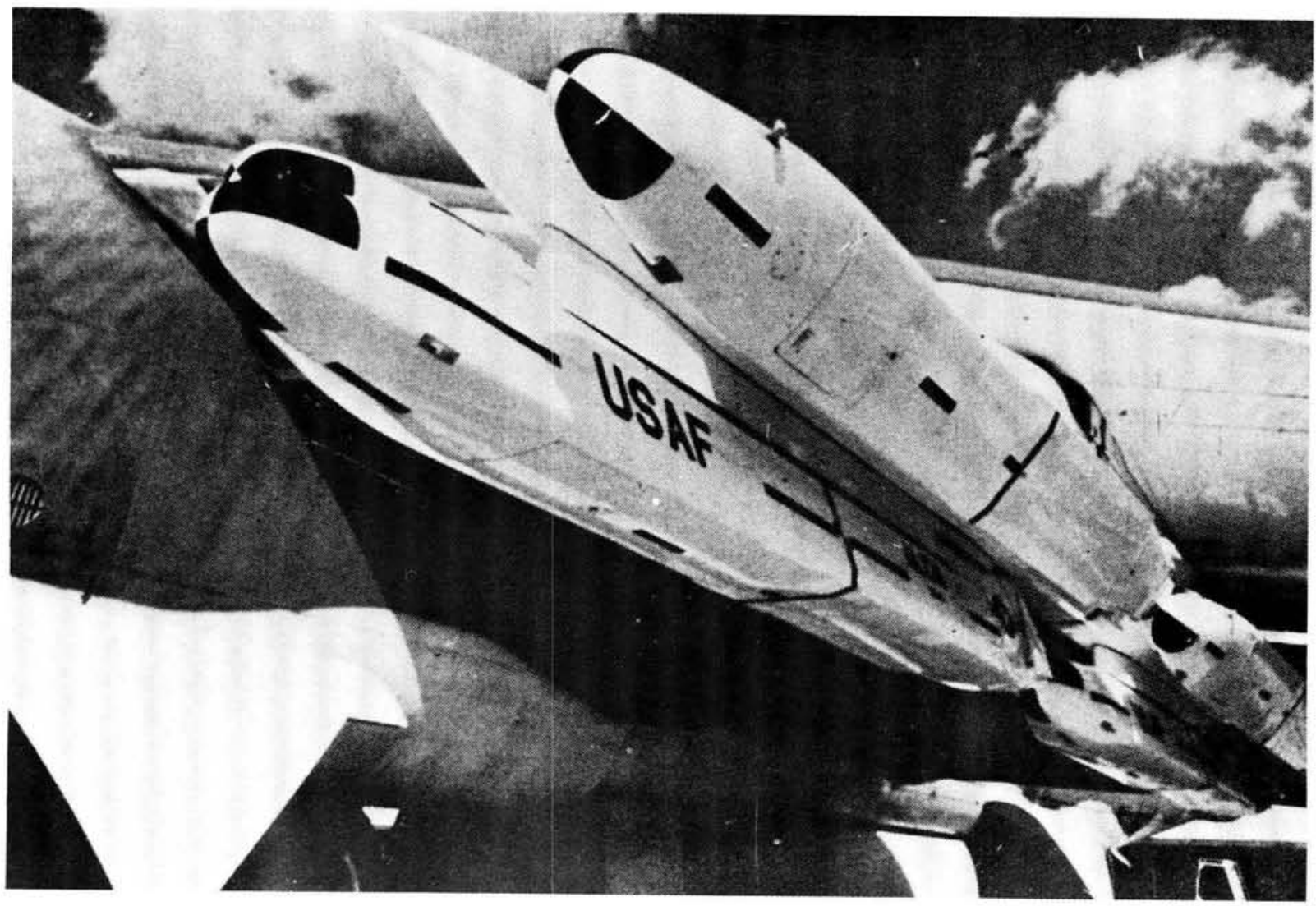


Lockheed C-5A en DC-10; kernduikbote en oppervlakte skepe) en mobiele platforms op land. ${ }^{23}$

\subsection{Strategiese betekenis van die kruisermissiel}

Die kruisermissiel het besliste strategiese voordele in terme van algemene oorlewingspotensiaal, alhoewel daar ook enkele beperkende aspekte aan hierdie wapen gekoppel is. Onder die vernaamste implikasies van hierdie wapentuig tel sy akkuraatheid, waar die identifisering van 'n teiken gelykstaande aan die vernietiging daarvan gereken kan word, en die 'harde teiken'vernietigingsvermoë wat uit die voorafgaande spruit. Die kruisermissiel lewer ernstige probleme vir enige deurbrake wat ten opsigte van projektielafweervermoëns behaal is, en sal tot tyd en wyl hierdie situasie verander, as 'n relatief onkwesbare wapentuig bestempel kan word. In vergelyking met die ICBM is die kruisermissiel vanweë sy laer spoed en beperkte reaksievermoë ' $n$ minder effektiewe wapen, maar indien faktore soos sy akkuraatheid, grootte en aanwendbaarheid vanaf verskillende platforms, sowel as koste-effektiwiteit in berekening gebring word, word sy algemene doeltreffendheid aansienlik verhoog. ${ }^{24}$

Die kruisermissiel kan 'n merkbare verbetering met betrekking tot die strategiese lugvermoë van ' $n$ kernmoondheid tot gevolg hê en daardeur een van die belangrike bene van die strategiese kerntriade (ICBM, bomwerpers, kernduikbote) versterk. Vanweë die kruisermissiel se reikvermoë (ongeveer 2000 kilometer) kan strategiese bomwerpers brandstofhervulling in die lug vermy en hoef dit nie die vyandelike lugruim binne te dring om teikens te vernietig en daardeur sy eie kwesbaarheid te verhoog nie. Hierbenewens kan die kruisermissiel se lanseerplatform in die lug tussen verskillende bomwerpers en ander vliegtuie wissel sodat dit oor 'n buigsame aanwendingsvermoë beskik. Ter see is die kruisermissiel ' $n$ strategiese reserwe en aanvullend tot die bestaande ontplooiing van ballistiese missiele op kernduikbote. ${ }^{25}$

Die gaping tussen die interkontinentale ballistiese missiel en die kortafstand offensiewe missiel ('short range attack missile' - SRAM) word deur die kruisermissiel gevul. Die kruisermissiel versterk hierdeur nie alleen 'n strategiese kernvermoë nie, maar bied ook moontlikhede op die terrein van taktiese kernwapentuig en konvensionele vermoëns. Pfaltzgraff merk in hierdie verband juis op dat namate die grens tussen strategiese- en taktiese kernwapens vernou, dit die einde kan beteken van die tot dusver streng bilaterale Sowjet-Amerikaanse forums vir die oorweging van strategiese kernwapenaangeleenthede. ${ }^{26}$ Die implikasie van bogenoemde aangeleentheid verhoog volgens die voorstanders van wapenkontrole en ontwapening die moontlikheid van verdere verspreiding van kernwapens, aangesien die grootste struikelblok vir potensiële kernmoondhede, naamlik 'n betroubare afleweringsvermoë, oorbrug word deur die lanseermoontlikhede van kruisermissiele. ${ }^{27}$ Motiverings ten opsigte van wapenkontrole en argumente oor die strategiese relevansie van die kruisermissiel, sowel as die moontlikheid van deurbrake in lugverdediging, word as die vernaamste besware teen die ontplooiing van hierdie wapentuig voorgehou. ${ }^{28}$

Die eksakte geleiding en die vernietigingsvermoë van die kruisermissiel, deur sy verskillende treffende tegnologiese eienskappe meegebring, lewer ten slotte ' $n$ ander belangrike gevolgtrekking wat saamgevat kan word in die woorde van Digby: '.. the technology for precision delivery has come at just the time when Western strategy is turning towards the threat of carefully controlled combat - both in regional and in intercontinental conflict - as a more credible deterrent than the threat of unrestrained response'. ${ }^{29}$

\section{Die neutronplofkop vir kernmissiele}

\subsection{Die ontwikkeling en die effek van die neutron- bom}

Die moontlikheid van die ontwikkeling van 'n bestralingstipe wapen ('enhanced-radiation weapon') het ontstaan na die vervaardiging van die waterstofbom in die laat veertigerjare. Die Lawrence Livermore Laboratory in Amerika het gedurende die vyftigerjare spesifiek in hierdie verband navorsing gedoen, en in 1963 is die eerste 'neutronbom' ondergronds te Nevada getoets. Projekte vir die vervaardiging van die neutronbom was hierna toegespits op spesifieke taktiese ontwikkeling en het ook ter sprake gekom by die vervaardiging van projektielafweerwapens, waar ' $n$ wapen vereis is wat inkomende missiele op kort afstand kan vernietig sonder om skade aan stede te berokken. ${ }^{30}$

Die belangstelling met betrekking tot taktiese kernwapentuig, veral vanweë NAVO se verantwoordelikheid in Europa, het die gedagte van die neutronbom al hoe meer op die voorgrond 
geplaas. Daar was spesifieke behoefte aan 'n wapen waarmee Wes-Europese lande beskerm kon word teen 'n konvensionele aanval deur die Warskou-verdragslande, sonder dat eie magte of grondgebied skade berokken sou word. Die debat oor konvensionele- en kerntaktiese vermoëns in Wes-Europa het in 1976 uitgeloop op die bekragtiging deur president Ford vir die ontwikkeling van neutronplofkoppe vir die Lancemissiel en spesifieke artillerie wapentuig. In wese word die ontplooiing van die neutronbom in Wes-Europa gemotiveer deur die ondersteuning wat dit sou verleen aan die afskrikkingstrategie tussen die Weste en die Ooste. ${ }^{31}$

Die neutronplofkop is 'n verhoogdebestralingswapen met ' $n$ beperkte verwoestingsvermoë ('reduced blast and heat weapon') wat tydens ontploffing vinnig-bewegende neutrone vrystel wat mense binne die bereik daarvan dood. Skade word nie noodwendig aan geboue of byvoorbeeld tenks aangerig nie, alhoewel die personeel daarbinne gedood kan word - daar word soms hierna verwys as ' $n$ 'skoon' waterstofbom. Die oënskynlike effek ten gunste van die materiële wat hierdeur verkry word, laat Sommer die volgende opmerk: 'With this bomb man has banished himself from the centre of things to the perimeter. Material has now taken over the central position'. ${ }^{32}$

Die openbare reaksie oor die effek van die neutronbom is wyd en uiteenlopend. Aan die een kant word hierdie wapen gesien in die tradisionele benadering dat oorlogswapentuig nog altyd daarop gemik was om die vyand te dood, en dat die neutronbom hierbenewens 'minder afgryslik' is as ander verwoestingswapentuig. Aan die ander kant word die neutronbom bestempel as 'super-kapitalisties' of 'kannibalisties' en geoordeel in dieselfde kategorie as biologiese- en chemiese oorlogvoering. Kensketsend van die propaganda-teenstand in Wes-Europa oor die ontplooiing van sodanige wapentuig, en die besluitnemingsonus wat in hierdie verband op die skouers van oud-president Carter gerus het, is die onderskrif by ' $n$ spotprent in die Washington Post: 'It's the Cartron bomb - it knocks down supporters without damaging opponents'. ${ }^{33}$

\subsection{Die aanwending en implikasies van die neutronbom}

Die neutronbom is primêr bedoel as defensiewe wapentuig in ' $n$ taktiese aanwendingsrol. Die aanwending daarvan teen 'n konsentrasie van vyandelike magte in aanmars - veral dié in gepantserde kolonne - sonder om skade te berokken aan uitrusting, installasies en bevolkingskonsentrasies, word as een van die belangrikste funksies van die neutronbom beskou. Die bekendste voorbeeld in hierdie verband is die verwysing na NAVO-teenoptrede in die geval van 'n konvensionele inval vanuit Rusland op WesEuropa - optrede wat veral belangrik kan wees indien NAVO-magte nie in staat sou wees om so 'n inval konvensioneel af te weer nie. ${ }^{34}$

Verskeie argumente en besware is teen die voorgestelde aanwendingsrol van die neutronbom geopper en kan uiteindelik terug herlei word na die algemene dilemma rondom die aanwending van taktiese kernwapentuig. Die risiko bestaan dat die aanwending van die neutronbom in konvensionele konflikte die moontlikheid van kerneskalasie kan verhoog. Hierbenewens is daar geen duidelikheid oor die newe-effekte wat kan ontstaan as gevolg van die aanwending van hierdie wapentuig nie. In sekere gevalle word dit bereken dat persone wat aan 'n neutron-aanval onderworpe was nog etlike ure daarna kan bly leef, en met die besef dat die dood weldra sal intree, kan dit ' $n$ verbete en morbiede oorlogstemming skep. ${ }^{35}$

Die aanwending van die neutronbom in suiwer taktiese- en konvensionele verband kan nie gereken word as ' $n$ metode waarop die verloop van 'n 'kernkonflik' moontlik veilig beperk en beheer kan word nie. Die neutronbom moet gereken word as ' $n$ kernwapen en dat sy aanwending moontlik kan lei tot kernkonfrontasie. In hierdie konteks vervul dit sy funksie primêr as afskrikkingswapen en moet die strategiese- en politieke implikasies daarvan deeglik verreken word, sodat dit nie aangewend sal word, in die waarskuwing van Sommer uitgedruk, ..... (in) making an atomic war without tears possible'. ${ }^{36}$

Die aanwending van die neutronplofkop tesame met strategiese kernmissiele het opmerklik uiters beperkte aandag geniet in vergelyking met die taktiese aanwending daarvan, alhoewel dit oor 'n potensiële strategiese aanwendingsvermoë beskik. Die neutronbom beskik oor 'n uitstekende deurdringingsvermoë in die geval van aanwending teen passiewe beskermingsmaatreëls in digbevolkte stedelike gebiede van die kernopponent (Sowjet passiewe burgerlike beskerming oortref soortgelyke maatreëls in die Weste by verre). Die aflewering van neutronplofkoppe deur kruisermissiele word verder gereken as een van die potensiële opsies wat in 'n strategiese aanwendingsrol verreken kan word. Die kruiser- 
missiel sal sodanige plofkop akkuraat op spesifieke stedelike teikens kan aflewer. Hierbenewens is die kruisermissiel vanweë sy beperkte reaksievermoë 'n vergeldingswapen en kan die aanwending van die neutronbom in hierdie verband dus teruggehou word tot die gebruik daarvan 'geregverdig' sou wees. Die aanwending van die neutronplofkop tesame met strategiese kernmissiele moet dus geëvalueer word in die breë kernstrategiese raamwerk van oorlewingspotensiaal en 'n strategie van afskrikking, sowel as by die verrekening van besware daarteen en die implikasies daarvan op wapenkontrole. ${ }^{37}$

\section{Slot}

Verskeie ontwikkelingsaspekte van kernmissiele, waarvan maar slegs enkeles in die voorafgaande gedeeltes uitgelig is, dui daarop dat die tagtigerjare gekenmerk gaan word deur belangrike militêr-tegnologiese verwikkelinge in kernstrategie. In hierdie verband is dit nie net die wapenwedloop wat die internasionale kerndebat oorheers nie, maar ook die vermoë van die superkernmoondhede om kernkonflik te vermy, deur onder andere geloofwaardige opponerende kernvergeldingsvermoëns in stand te hou. In hierdie toestand van delikate tussenstaatlike terreurewewig speel militêr-tegnologiese verwikkelinge ' $n$ baie belangrike rol, soos Kissinger aandui: 'The penalty for miscalculation in the technical field is obvious and demonstrable. The penalty for falling behind in the field of strategic doctrine, though catastrophic, is not immediately discernible. Mastering the technical problems is so difficult that it leaves little time for considering the strategic implications of the new technology'. ${ }^{38}$ Strategiese kernparaatheid is gevolglik ' $n$ sleutelvereiste vir die magsbalans tussen die Weste en die Ooste.

Lt T. van Rensburg, MA het sy graad aan die begin van 1981 met lof aan die Universiteit van die OVS behaal.

\section{Voetnotas:}

1. Vgl. Polmar, N., Strategic Weapons: An Introduction, National Strategy Information Centre, New York, 1975, pp. 36-37; Beard, E., Developing the ICBM. A Study in Bureaucratic Politics, Columbia University Press, New York, 1976, pp. 208-209.

2. Vgl. loc cit. Die VSA kon egter eers in 1964 daarin slaag om die dravermoë van die Sputnik 3 wat in Mei 1958 gelanseer is, te ewenaar.

3. Beard skryf soos volg hieroor, op. cit., pp. 6-7: "The Sputnik launch, and the ICBM capability it demonstrated, were of enormous symbolic importance. American international prestige and American domestic selfperception and self-confidence were strongly shaken. Although the change may have been primarily symbolic, something had been significantly altered. The United States was no longer seen, by other nations or by its own citizens, in quite the same light. In an area of great potential significance, the United States was suddenly and demonstrably second. In addition one of the strongest fears underlying much of the 'missile gap' scare was that the Soviet Union might be able, by taking advantage of its development lead, to gain a first-strike capability against the United States that could not be answered.'

4. Vgl. Ibid., pp. 1-13. Beard skryf oor die uitwissing van bogenoemde 'agterstand' da: die Kennedy Administrasie 'undertook the largest and fastest peacetime military buildup in the history of the United States'

5. Vgl. The Missile Tables, in Defense and Foreign Affairs, Vol. VIII, No. 3,1980, p. 30 . Die breë stand van sake tov verskillende missiele kan geraadpleeg word in Taylor, M. J. H., Taylor, J. W. R., Missiles of the World, lan Allan Ltd., London, 1976.

6. Vgl. Greenwood, T., Making the MIRV: A Study of Defence Decision Making, Ballinger Publishing Co.. Cambridge, 1975, pp. 3-4.

7. Aangehaal in Tammen, R. L., MIRV and the Arms Race. An Interpretation of Defence Strategy, Praeger Publishers, New York, 1973 , p. 72

8. Vgl. Polmar, N., op. cit., pp. 61-63; Greenwood, T., Making the MIRV . pp. 4-11.

9. Greenwood, T., Making the MIRV ...., p. 81 (vgl. verder pp. 142-143). Vgl. ook Tammen, R. L., op. cit., pp. 97-107.

10. Vgl. Greenwood, T., Making the MIRV ...., pp. 2-3, 167-169; York, H. F.. Multiple-Warhead Missiles, in Scientific American, Vol. 229, No. 5, November 1973 , pp. 18-19.

11. Vgl. loc. cit.

12. Vgl. York, H. F., op. cit., pp. 24-25; Polmar, N., op. cit., pp. 64-66. Vgl. ook die kwesbaarheid van silogebergte kernmissiele die bydra van Gray, C. S., The Strategic Forces Triad: End of the Road, in Foreign Affairs, Vol. 56, No. 4, Julie 1978, pp. 771-789.

13. Vgl. Tammen, R. L., op. cit., po. 111-126. Tammen verduidelik hierdie verbetering en verandering soos volg: "this transition supplies direct evidence of the influence of changing technology on military strategy. It illustrates how a discredited strategy remained alive, even though officially rejected, until changing technological condition provided a suitable base for its resurrection".

14. Vgl. Ibid., pp. 131-136; Potter, W. C., Coping with MIRV in a MAD World, in The Journal of Conflict Resolution, Vol. 22, No. 4, Desember 1978 , pp. 599-624.

15. Ashmore, E. B., Guided Missiles. Fiction and Reality, in NATO's Fifteen Nations, Vol. 17, No. 1. Februarie/Maart 1972, p. 54

16. Vgl. Pfaltzgraff, R. L., Davis, J. K., The Cruise Missile: Bargaining Chip or Defense Bargain?, hoofstuk 1, in NATO's Fifteen Nations, Vol. 22. No. 3, Junie/Julie 1977 , pp. 30-31.

17. Vgl. Ibid., p. 31; Digby, J. F., Precision Guided Weapons, in Adelphi Papers, No. 118, Summer 1975, pp. 1-4; Tsipis, K., Cruise Missiles, in Scientific American, Vol. 236, No. 2, Februarie 1977, p. 22: Buchanan, L. F., Cruise Missiles Takes Shape, in Defense and Foreign Affairs, Vol. VII, No. 2, 1980, pp. 30-31.

18. Tsipis, K., Cruise Missiles ... . p. 20.

19. Vgl. Marriot, J., Precision Guided Munitions, in NATO's Fifteen Nations, Vol. 22, No. 5, Oktober/November 1977, pp. 115-121; Ashmore, E. B., op. cit., pp. 54-55. Vgl. ook Digby, J. F., op. cit., p. 4: "Accuracy is no longer a strong function of range, and if a target can be acquired it can usualy be hit. For many targets, hitting is equivalent to destroying."

20. Vgl. Pfaltzgraff, R. L., Davis, J. K., op. cit., pp. 31-32; Tsipis, K., Cruise Missiles... pp. 21-23.

21. Vgl. loc. cit.

22. Vgl. Tsipis, K., Cruise Missiles.... pp. 20-24; en Pfaltzgraff, R. L. Davis, J. K., op. cit., pp. 32-33.

23. Vgl. Tsipis, K., Cruise Missiles ..... pp. 23-25; Pfaltzgraff, R. L. Davis, J. K., op. cit., pp. 33-38, 42; Ball, D., The Costs of the Cruise Missile, in Survival, Vol. XX, No. 6. November/Desember 1978 , pp. 242-247.

24. Vgl. Pfaltzgraff, R. L., Davis, J. K., op. cit., pp. 38-43; Tsipis, K., Cruise Missiles...., pp. 27-28. Vgl. ook Digby, J. F., op. cit., pp. 4-6 oor die toekomsmoontlikhede van eksakte geleide-tipe wapentuig.

25. Vgl. Pfaltzgraff, R. L., Davis, J. K., op. cit., pp. 38.43

26. Vgl. Pfaltzgraff, R. L., The Evolution of Strategic Weapons Policies, in RUSI and Brassey's, Weapons Technology, Brassey's Publishers, London, Tweede Uitgawe, 1978, pp. 25-29.

27. Vgl. Vershbow, A. R., The Cruise Missile: The End of Arms Control?, in Foreign Affairs, Vol. 55, No. 1, Oktober 1976, pp. 141-142. Vgl. ook Pfaltzgraff, R. L., Davis, J. K., The Cruise Missile: Bargaining Chip or Defense Bargain?, hoofstuk 2, in 
NATO's Fifteen Nations, Vol. 22, No. 4, Augustus/September 1977, pp. 26-23 oor die moontlikhede van die ontplooiing van die kruisermissiel in NAVO verband.

28. Vgl. Tsipis, K., Cruise Missiles ..., pp. 27-29; Gray, C. S., Who's Afraid of the Cruise Missile?, in ORBIS, Vol. 21, No. 3, Fall 1977. pp. 517-531.

29. Digby, J. F., op. cit., p. 11.

30. Vgl. Kaplan, F. M., Enhanced-Radiation Weapons, in Scientific American, Vol. 238, No. 5, Mei 1978, pp. 44-46; Sommer, T., The Neutron Bomb: Nuclear War Without Tears?, in Survival, Vol. XIX, No. 6, November/Desember 1977, pp. 263-264; Kistiakowsky, G., The Folly of the Neutron Bomb, in The Bulletin of the Atomic Scientists, Vol. 35, No. 7, September 1978, p. 25.

31. Vgl. Sommer, T., op. cit., p. 264; en Kistiakowsky, G., op. cit., pp. 25-26.

32. Sommer, T., op. cit., p. 264. Vgl. Kaplan, F. M., op. cit., pp. 46-49 Cohen, S. T., Enhanced Radiation Warheads: Setting the Record Straight, in Strategic Review, Vol. VI, No. 1, Winter 1978, pp. 9-17 vir verdere detail oor die effek van die neutronplofkop.

33. Aangehaal en geillustreer in die artikel Furor Over the Neutron
Bomb, in Newsweek, Vol. 91, No. 16, 17 April 1978, p. 17. Vgl. verder oor bg. reaksie Cohen, S.T., op. cit., pp. 9-10; Carr, B., The Neutron Bomb: Proceed but with Caution, in NATO's Fifteen Nations, Vol. 22, No. 6, Desember 1977 - Januarie 1978, pp. 50-54.

34. Vgl. Carr, B., op cit., pp. 50-51; Kaplan, F. M., op. cit., pp. 47-48; Black, E. F., Cohen, S. T., The Neutron Bomb and the Defence of NATO, in Military Review, Vol. LVIII, No. 5, Mei 1978, pp. 53-61

35. Vgl. Kaplan, F. M., op. cit., pp. 49-50; Snow, D. M., Strategic Implications of Enhanced Radiation Weapons. A Preliminary Analysis, in Air University Review, Vol. XXX, No. 5, Julie/Augustus 1979 , pp. 7-8.

36. Sommer, T., op. cit., p. 266. Vgl. ook Carr, B., op. cit., p. 54 ; Kaplan, F. M., op. cit., pp. 50-51

37. Vgl. Snow, D. M., op. cit., pp. 8-15. Snow sluit sy bespreking soos volg af: "Regardiess of the conclusions regarding strategic implications of enhanced-radiation warheads, the technology is available, and the options need to be analysed.

38. Kissinger, H. A., Nuclear Weapons and Foreign Policy, Harper and Brothers, New York, 1957, p. 18. 